\title{
Gnostic Apocalypse and Islam: Quran, Exegesis, Messianism, and the Literary Origins of the Babi Religion,
}

by Todd Lawson (Iranian Studies, 12) (London \& New York: Routledge, 2012), vii + 230 pp., ISBN: 978-0-415-49539-4, £80 (hb)

The title, circumstantial and long-winded as it is, bears witness to a protracted process of maturity. The author addressed the topic in his PhD thesis (McGill Univ., 1987), and he has apportioned the material to a series of articles presented at a number of relevant conferences. He stands within a tradition: the origins of Bābism (and, in its wake, the Bahā'ì religion) attracted E. G. Browne's interest when he spent "A Year amongst the Persians" in 1887-1888, and anglophone scholarship followed with works written by Hasan Balyuzi (1973), Denis MacEoin (1979, 1992, 2009), and Abbas Amanat (1989). The present book (140 pages of text with 34 pages of endnotes) addresses the philological hub of the problem, the Bāb's Tafsìr sūrat Yüsuf, a strange product of religious Schwarmgeisterei that is anything but what it pretends to be, namely exegesis. Sūra 12 of the Qur'ān serves as a mere gimmick; the "commentary" rarely refers to the scriptural basis but accumulates a multitude of enigmatic allusions that must be decoded in the process of reception. Most of these statements conjure up the Qur'ān itself, but on the basis of a specific interpretation that could develop only in a late Iranian intellectual milieu after the spread of the Shaykhī movement. The Tafsì itself was subdivided into 111 "sūras" of 42 verses each (because 42 is the numerical value of the word bala, the answer given by mankind to the famous a-last question in Q 7:172).

The Bāb was 25 years old when he wrote this text. The Qur'ān was constantly on his mind, but his knowledge of Arabic syntax was deficient. He had, of course, a message to relate: that Islam had reached an apocalyptic moment at which a hitherto unspoken truth was to be revealed. He saw himself as the mouthpiece of the Hidden Imām who had been in ghayba for exactly one thousand years (in $1260 \mathrm{H}$ ), and he was ready to proclaim a new age in which he, as the Mahdī, would abrogate the Law and ultimately assume divinity (cf. p. 131, where he has Joseph (or the Imām?) say, innì ana llāh alladhì lā ilāha illā ana). Instead of divinity, however, he found multiple im- 
prisonments and, temporarily, even recantation. When his adherents began rioting, the government intervened, and he was executed (in 1266/1850), not without having undergone during his trial an examination of his idiosyncratic usage of Arabic. The "Gate" had only been a merchant and had never seen a madrasa from the inside.

The author of the present book is not concerned with factual history; the story of the Bāb has been told many times since the days of E. G. Browne and the Comte de Gobineau. Rather, he is interested in structural analysis and the oddities of pseudo-prophetic language. With this in mind, he delves into earlier texts of Twelver-Shī' " "Gnosticism:" 'Alī's apocryphal Khuṭba Tutunjiyya (pp. 84 ff.); the Mashāriq anwār al-yaqīn, written by Rajab al-Bursī (d. after $810 / 1410$, a man from a village in Iraq known to German archeologists as ancient Borsippa); Aḥmad al-Aḥsā'̄'s Sharḥ al-ziyāra aljāmi ‘a; and Kāẓim Rashtī's Sharh al-Qașīda al-lāmiyya. He attempts to elucidate the Bāb's opaque style and explains why his hero could pretend to be the Fire in the Light of Q 24:35 (because nār, "fire," has the numerical value of 251 and nür, "light," 256, so that $b \bar{a} b=5$ can be used to fill the gap; cf. p. 133). He devotes an entire chapter (pp. 46-74) to the self-predications Bāb and Dhikr (a topic tentatively treated by the author in 1988, in an article contributed to the Studies in Honor of the Late Hasan M. Balyuzi). In the end, he edits "sūra" 93, the sürat al-Naḥl ("The Bees") of the Bāb's Tafsìr (pp. 145-149), together with an English translation and a learned (though somewhat disconnected) commentary (pp. 93-139). Inevitably, Lawson's diction tends to be as associative as the Bāb's, hopping from one parallel to another in search of precedents and practicing the same sort of "metalepsis" he finds typical of the Bāb's treatment of Joseph (cf. p. 93 in the heading of chapter four, where, however, this rather technical term is never explained). In fact, the Bāb's opacity has a charm of its own; the author compares it to the "chaos of light" in the paintings of William Turner (p. 135). He succeeds in clarifying a number of obscure passages; the reader can justly hope to be relieved of his blindness as was Jacob when Joseph's shirt was laid upon his eyes ( $Q$ 12:93; cf. p. 93 f.). When an overview or a summary is needed, Lawson occasionally refers to Henry Corbin's En Islam iranien, in which the Bāb appears on the scene in the chapter on the Shaykhiyya (vol. IV, $205 \mathrm{ff}$.). He does not forget to mention, however, that Corbin was aware of the difference between both phenomena (vol. IV, $282 \mathrm{f}$, quoted p. 171, n. 28). It was only the Bāb who thought in terms of a 
new cycle in which the waiting had come to an end. This is why he identified himself with Joseph; from the beginning, he seems to have seen himself as a new prophet whose Gabriel was the Hidden Imām.

The book is rendered accessible by a meticulous and very detailed index. The bibliography, in contrast, occasionally leaves the reader at a loss. Afterthoughts added to the text seem to have not always been registered there. In p. 178, n. 47, two books by (S.) Bashir are mentioned in an abbreviated form without being addressed in the bibliography; the same type of oversight appears in p. 183, n. 117, with "Landolt, H. Corbin" and "Katz," and in p. 184, n. 1, with Todorov's Symbolism (where the proper name has been misspelled as "Todorv"). Moreover, one must check the "Abbreviations" first (p. 185 f.); the items mentioned there are not repeated in the bibliography. On p. 19, "Huart Clement" should be corrected to "Clément Huart." There are a few misprints: p. 201 read "Pourjavady" instead of Poujavardy; p. 69 "aḥwal" instead of $a h w w a \bar{l}$; p. 78 "Hūriyya" instead of Hürriyya (i.e., sūra 29 of the Bāb's Tafsìr, cf. p. 43); p. 108, v. 5 "dhululan" instead of dhalūlan; p. 128 "al-sā'ati" instead of al-sa'āti; p. 133 "mishkāt" instead of mishkā; p. 71 "emissaries" instead of emmissaries; p. 72 "Resurrector" instead of Ressurector. I wonder whether sirr lā yufídubū illā sirr can be rendered "a secret that can only speak of a secret" (p. 123). Would it not be better to say, "a secret that only discloses itself by way of another secret" (a secretum secretorum, as it were)? Can mudawwira really be "revolving" ( $\mathrm{p}$. 117)? This would be dawwār, or perhaps mudawwar. Of course, we are dealing with the Bāb's Arabic, not with ours. But do English grammar books ever speak of a "dual plural" (p. 67)? In some cases, a dual can be formed from broken plurals (Wright, A Grammar of the Arabic Language, vol. I, $190 \mathrm{ff}$.), but this is not what is meant here.

The book provides a large amount of material and contributes to a better understanding of a difficult text.

Josef van Ess Eberhard Karls Universität Tübingen, Tübingen-Germany 